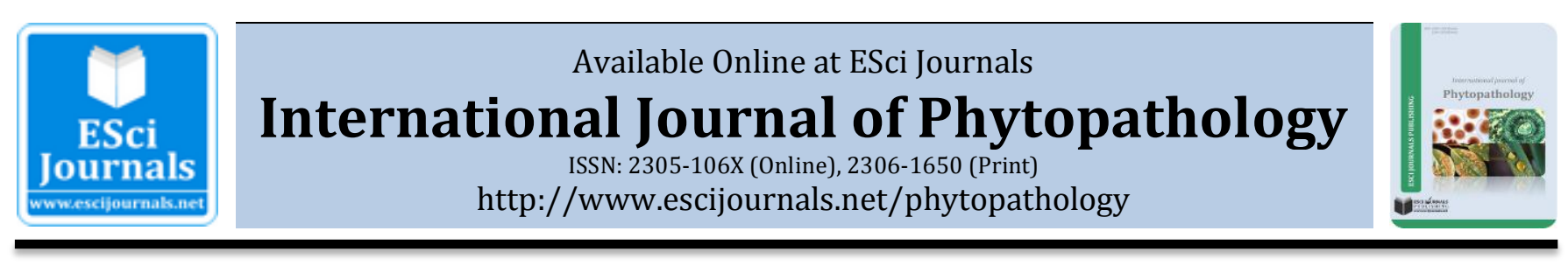

\title{
DISEASES OF PLANTATION FORESTRY TREES IN SOUTHERN GHANA
}

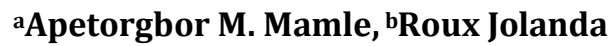 \\ a Forestry Research Institute of Ghana, P. O. Box 63, KNUST, Kumasi, Ghana. \\ ${ }^{b}$ Forestry and Agricultural Biotechnology Institute (FABI), University of Pretoria, South Africa.
}

\begin{abstract}
A B S T RA C T
Ghana is on the verge of exhausting its timber resources and has embarked on reforestation. However, the establishment of pure stands of high value indigenous tree species such as Odum (Milicia excelsa and M. regia), Mahogany (Khaya and Entandrophragma species) and Kokrodua (Pericopsis elata) were not successful as a result of insect pest and disease problems. These failures, together with the need to establish plantations partly account for the widespread planting of teak (Tectona grandis), cedrela (Cedrela odorata) and other introduced tree species. Disease outbreaks in Tectona grandis, Cedrela odorata and Ceiba pentandra have been observed with the expansion of plantation estates. A study was therefore conducted to identify key diseases occurring in tree plantations, determine their distribution and evaluate management strategies to contain them. Diseases encountered include root rot caused by Armillaria hemii on T. grandis and Cedrela odorata, leaf spot and dieback on Ceiba pentandra seedlings and saplings caused by Colletotrichum capsici, Fusarium solani and Lasiodiplodia theobromae, stem canker on Eucalyptus spp. caused by Botryosphaeria sp. and leaf blight caused by a Calonectria species. Management of these diseases will require training of foresters on tree health issues, quarantine and silvicultural practices and initiation of sound breeding and selection programmes.
\end{abstract}

Keywords: Armillaria hemii, Botryosphaeria sp., Lasiodiplodia theobromae, indigenous and introduced trees, pure stands.

\section{INTRODUCTION}

Ghana has one of the highest rates of deforestation in West Africa (Benhin and Barbier, 2001). Between 1990 and 2000, the average estimated annual rate of deforestation was high (2\%), covering approximately 135,000 hectares (FAO, 2010a). It was estimated by Ghana's Ministry of Environment and Science (2002) that less than $1 \%$ of the forest cover was found outside forest reserves, much of it being in small scattered patches in swamps and sacred groves. This prompted the Government to initiate a National Forest Plantation Development Programme which resulted in the establishment of 120,000 hectares of forest plantations by the end of 2007, to supplement timber from the natural forest and sustain its supply for domestic and international markets (Forest Commission, 2007). These plantations are predominantly made up of non-

\footnotetext{
* Corresponding Author:

Email: mape@csir-forig.org.gh

(C) 2015 ESci Journals Publishing. All rights reserved.
}

native species such as Tectona grandis, Cedrela odorata, Gmelina arborea, Pinus caribaea and Eucalyptus spp. with $T$. grandis alone constituting well over $70 \%$. Native tree species included in the Plantation project were Mansonia altissima, Terminalia superba, Terminalia ivorensis, Ceiba pentandra, Heritiera utilis, Entandrophragma angolense and Triplochiton scleroxylon (Foli et al., 2009).

Establishment of many of the species was on a very small scale and limited to a narrow range of habitats and conditions. This reduced the chances of pest and disease outbreaks on these trees. However, with the establishment of pure stands over increasingly large areas the threat of disease problems has increased.

Some diseases hitherto unknown in Ghana have thus been observed recent times. The establishment of Milicia excelsa (Odum), for example, has been hindered by the attack of Phytolyma lata, which predisposes the plant to dieback (Wagner et al., 2008). Besides, Lasiodiplodia theobromae and 
Fusarium solani have been associated with dieback and decline of M. excelsa seedlings (Apetorgbor et al., 2003b). Attempts made in raising seedlings of Ceiba pentandra in nurseries and establishment in plantations have been hampered by leaf spot resulting in dieback. Colletotrichum capsici was isolated from the leaf spot while Fusarium solani and Lasiodiplodia theobromae were found associated with dieback of stems in both the nursery and field (Apetorgbor et al., 2003a). The establishment of Khaya senegalensis has been abandoned because of root rot by Pseudophaeolus baudonii which caused serious problems in mahogany plantations (Ofosu-Asiedu, 1988). Pseudophaeolus baudonii also caused appreciable losses to plantations of Senna siamea, Eucalyptus citriodora, E. dagambae, Pinus caribaea and Tectona grandis (Ofosu-Asiedu, 1988). During disease surveys of Eucalyptus grandis, E. camaldulensis and E. dagambae plantations in the Ashanti, Central and Eastern Regions of Ghana, stem cankers on mature $E$. dagambae, which resemble that caused by species of Chrysoporthe were observed in a single compartment near Kumasi (Roux and Apetorgbor, 2009).

Among the plantations established, disease problems started emerging on Tectona grandis (Teak) and Cedrela odorata (Cedrela) plantations. Plantation developers reported that disease problems in these plantations are increasing in the Anhwiaso South, Kwamisa, Opro, Tano Nimri, Mamiri and Afram Headwaters forest reserves (Apetorgbor and Bosu, 2009).

This paper presents new disease outbreaks and pathogens affecting tree plantations in Ghana. It also discusses management strategies undertaken to reduce the impact of these problems.

\section{MATERIALS AND METHODS}

Study Area: Field surveys were conducted randomly in 31 plantation situated in degraded forest reserves based on reports on disease incidents received from the National Forest Plantation Development Programme and small scale plantations. The reserves included the Afram Headwaters, Opro, Asubima, Mankrang, Yaya, Tain II, Worobong South and Volta Block I forest reserves in the Dry semi-deciduous forest zone. The others included Kwamisa, South Formangso, Asenanyo, Jimira, Anhwiaso South, Bosomkese, Esuboni, Birim and Pra Anum forest reserves in the Moist semi-deciduous forest zone and Mamiri and Tano Nimri in the Moist evergreen forest zone. Visits were also made to the African Plantations for Sustainable Development (APSD) Ghana Limited at Kwame Danso in the Guinea Savannah woodland (Figure 1).

Field survey: The surveys were on Tectona grandis and Cedrela odorata plantations in all the forest reserves, Eucalyptus species in APSD and Ceiba pentandra plantations and nurseries in the Afram Headwaters, Jimira and Pra Anum forest reserves from 2006 to 2012 (Figure 1, Table 1). Informal discussions were held with communities around these reserves prior to the field assessments to determine the status of diseases in the plantations. Background information on establishment of the plantations including planting techniques, land clearings and site history was documented. Hundred trees each per hectare were selected for sampling and inspected individually. Trees suffering from root diseases were identified based on observation of both above and below-ground symptoms. Trees with cracks on stems and branches, canker, wilt, dieback and leaf spots were examined. To determine the extent of damage to trees within the plantations, three replicates per hectare of each plantation were sampled out for intensive assessment. Infected trees were classified using a five-point damage rating:

(i) Healthy (No visible sign of disease)

(ii) Minor damage (New infections with symptoms evident on bole; however, tree shows no sign of damage)

(iii) Moderate damage (Infection on bole and spreading, most leaves are necrotic and/or drooping, sap flow)

(iv) Severe (Over $75 \%$ of infected trees completely defoliated, heavy flow of sap/cracks at base of stem)

(v) Death of trees.

Samples of diseased leaves, stems, twigs and roots were collected for laboratory examination.

Laboratory studies: Morphological studies of fungal pathogens were conducted macroscopically and microscopically. Ascomycetes fungi were isolated using 2.0\% Malt extract agar (MEA) and Potato dextrose agar (PDA) supplemented with streptomycin sulphate (100ppm). For the isolation of Basidiomycetes, a selective medium containing benomyl and streptomycin sulphate was used.

Fungal colonies were isolated using identification keys (Brayford, 1997; Rivarden et al., 1994; Arora, 1986) as well as DNA sequence data (IGS and ITS gene regions). 


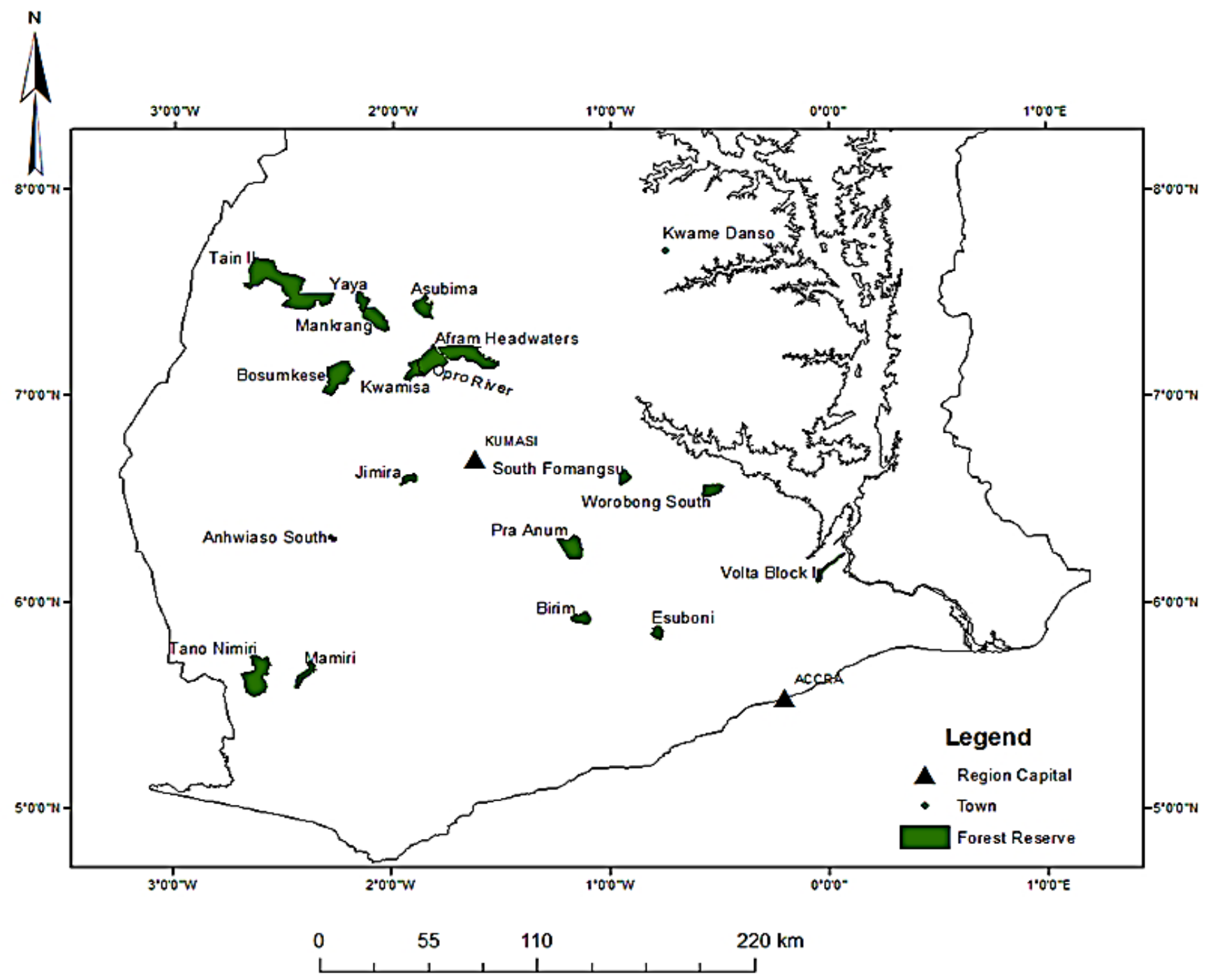

Figure 1. Distribution of plantations surveyed in forest reserves.

\section{RESULTS}

Disease incidence was variable depending on tree species, location and age.

Diseases of Tectona grandis: Ninety five percent of 17 teak plantations surveyed were free from diseases. However, teak mortality was observed in plantations around the Asubima, Afram Headwaters, Kwamisa, Mamiri and Opro forest reserves. Symptoms of poor tree health such as defoliation, dieback and stunted growth were recorded on trees as young as one year after planting while yellowing and dieback were observed in on pole-sized trees in the Yaya and Tain II forest reserves. Dying trees had their leaves yellowing from the crown and later died back. In Asubima and Kwamisa disease incidence was minor but moderate in pole-sized trees in the Afram Headwaters and Opro forest reserves.
Root rot was found in only three out of 17 plantations surveyed (Table 1). It was recorded in the Kwamisa, Mamiri and Tano Nimri plantations with mortality being severe in plantations in the Mamiri Forest reserve.

Distribution of disease was in isolated patches in all the plantations surveyed. For plantations in Asubima, Worobong South, Afram Headwaters and Opro, poor tree health was attributed to poor site factors. In Kwamisa, Mamiri and Tano Nimri the causes were as a result of root rot pathogen.

Symptoms above-ground were wilting, yellowing of leaves, bark cracking, defoliation and dieback. Severely infected trees shed their leaves and died eventually (Figure 2a). At the bases of tree trunks were rot which were advancing up the stem with white mycelia between the bark and wood of stem. 
Int. J. Phytopathol. 04 (01) 2015. 05-13

Table 1. Major disease outbreaks in forest reserves in Ghana (2006-2012).

\begin{tabular}{|c|c|c|c|c|c|c|c|c|}
\hline Host & Region & Forest Reserve & $\begin{array}{c}\text { Ecological } \\
\text { Zone* }\end{array}$ & $\begin{array}{l}\text { Age (Yrs.) of } \\
\text { plantations }\end{array}$ & Disease Status & $\begin{array}{l}\text { Disease } \\
\text { Severity }\end{array}$ & Causative Agent & Disease Distribution \\
\hline \multirow{17}{*}{$\begin{array}{l}\text { Tectona } \\
\text { grandis }\end{array}$} & \multirow[t]{8}{*}{ Ashanti } & Asubima & DS & $1-2$ & Mortality & Minor & Drought & Isolated \\
\hline & & & & $1-2$ & Defoliation/Dieback & Moderate & Drought & Isolated \\
\hline & & Opro & DS & $2-4$ & Defoliation/Dieback & Moderate & Drought/Hardpan & Scattered \\
\hline & & Afram Headwaters & DS & $2-4$ & Mortality & Moderate & Drought/Hardpan & Scattered \\
\hline & & \multirow[t]{2}{*}{ Kwamisa } & \multirow[t]{2}{*}{ MS } & $2-4$ & Dieback/Basal rot & Moderate & Armillaria sp. & Isolated \\
\hline & & & & 6 & Mortality/Basal rot & Minor & Armillaria sp. & Isolated \\
\hline & & Jimira & MS & $6-8$ & Nil & Nil & Nil & Nil \\
\hline & & Mankrang & MS & $1-2$ & Defoliation/Dieback & Moderate & Drought/Hardpan & Scattered \\
\hline & Brong & Yaya & DS & $2-4$ & Defoliation/Dieback & Moderate & Drought/Hardpan & Scattered \\
\hline & Ahafo & Tain II & DS & $2-4$ & Defoliation/Dieback & Moderate & Drought/Hardpan & Scattered \\
\hline & \multirow[t]{3}{*}{ Western } & Mamiri & ME-WE & 9 & Mortality/Basal rot & Severe & Armillaria hemii & Isolated \\
\hline & & Tano Nimiri & ME-WE & 6 & Mortality/Basal rot & Severe & Armillaria hemii & Scattered \\
\hline & & Anwhiaso South & MS & $2-3$ & Dieback & Moderate & Armillaria hemii & Isolated \\
\hline & \multirow[t]{4}{*}{ Eastern } & Pra Anum & MS & $6-8$ & Nil & Nil & Nil & Nil \\
\hline & & Worobong South & DS & 1 & Stunting & Moderate & Drought/Hardpan & Isolated \\
\hline & & Birim & MS & $6-8$ & Nil & Nil & Nil & Nil \\
\hline & & Volta Block I & DS-SM & $8-10$ & Dieback & Minor & Drought & Drought \\
\hline \multirow{6}{*}{$\begin{array}{l}\text { Cedrela } \\
\text { Odorata }\end{array}$} & Ashanti & Asubim & DS & $1-2$ & Mortality & Minor & Drought & Isolated \\
\hline & Brong & Yaya & MS & $1-2$ & Defoliation & Moderate & Poor site & Scattered \\
\hline & Ahafo & & & & Stunting & Minor & Drought/Hardpan & Scattered \\
\hline & Western & Mamiri & ME-WE & 9 & Basal rot & Severe & Armillaria hemii & Scattered \\
\hline & & Tano Nimiri & ME-WE & 9 & Basal rot & Severe & Armillaria hemii & Scattered \\
\hline & & & & 8 & Wind throwing & Minor & Drought/Hardpan & Isolated \\
\hline \multirow{4}{*}{$\begin{array}{l}\text { Ceiba } \\
\text { pentandra }\end{array}$} & \multirow[t]{3}{*}{ Ashanti } & Mankrang & MS & Nursery & Leaf spot & Severe & Colletotrichum sp. & Scattered \\
\hline & & Asenanyo & MS & $1-2$ & Dieback & Severe & Colletotrichum sp. & Scattered \\
\hline & & FORIG & MS & Nursery & Leaf spot & Severe & Colletotrichum sp. & Scattered \\
\hline & Eastern & Pra Anum & MS & 3 & Mortality & Moderate & Colletotrichum sp. & Scattered \\
\hline \multirow{4}{*}{$\begin{array}{l}\text { Eucalyptus } \\
\text { spp. }\end{array}$} & Brong & Kwame Danso & & & Cutting rot & Minor & Calonectria sp. & Isolated \\
\hline & Ahafo & & DS & & Leaf spot & Minor & Mycosphaerella sp. & Isolated \\
\hline & & & & Nursery & Leaf blight & Minor & Cylindrocladium sp. & Isolated \\
\hline & Central & Yenku & SM & $8-12$ & Nil & Nil & Nil & Nil \\
\hline
\end{tabular}

*DS: Dry Semi-deciduous; MS: Moist Semi-deciduous; ME-WE: Moist Evergreen-Wet Evergreen; SM: South Marginal 


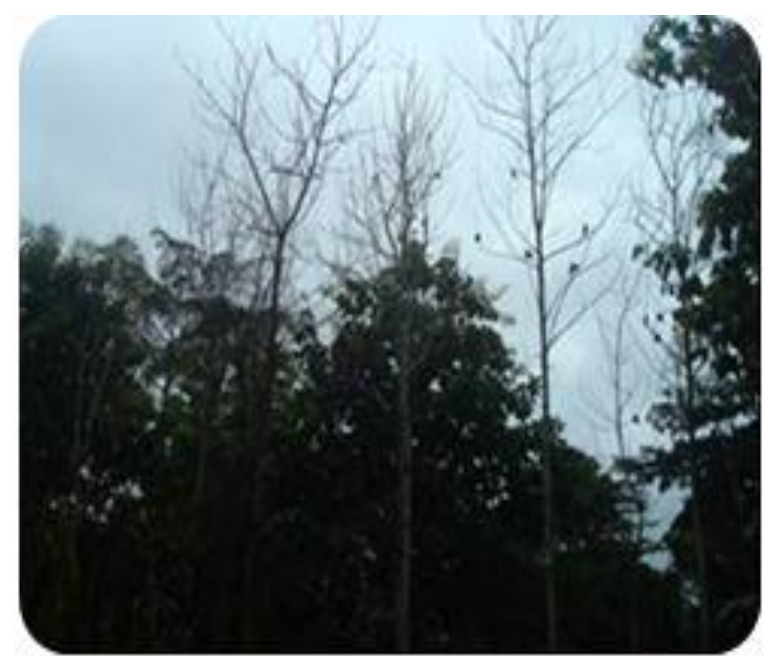

Figure 2a. Death of teak trees.

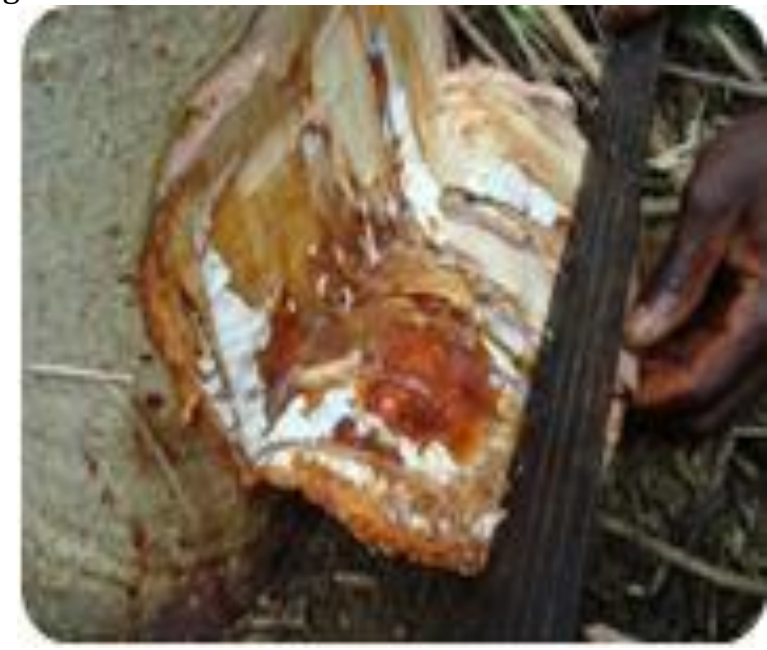

Figure 3a. White mycelia under bark of cedrela stem.

Table 2. Disease incidence in Cedrela odorata plantations.

\begin{tabular}{lcc}
\hline \multirow{2}{*}{ Tree Health Status } & \multicolumn{2}{c}{ Disease incidence (\%) in C. dorata plantations in } \\
\cline { 2 - 3 } & Mamiri & Tano Nimiri \\
\hline Healthy & 31.7 & 13.0 \\
Moderately diseased & 14.5 & 4.1 \\
Severely diseased & 36.5 & 61.6 \\
Death of trees & 16.3 & 21.3 \\
\hline
\end{tabular}

The incidence of disease was more severe in plantations in the Mamiri forest reserve with $1.2 \%$ of the trees infected with root rot. Macroscopic and DNA sequencing of isolates (fruit bodies) revealed Armillaria hemii complex as the pathogen (Figure $2 b$ ).

Diseases of Cedrela odorata: In plantations at the Tano Nimri and Mamiri forest reserves basal root rot was observed in $68.3 \%$ pole-sized trees. Disease was severe and scattered in the plantations. Bark of trees were cracked and decaying from the base up the stems, and leaves of newly attacked trees first turned yellowish and shed off as the infection advanced

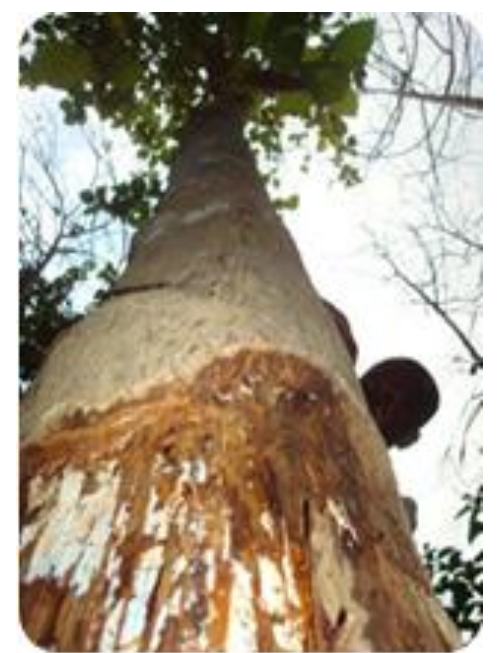

Figure $2 b$. Rot of stem with mycelia mat at base.

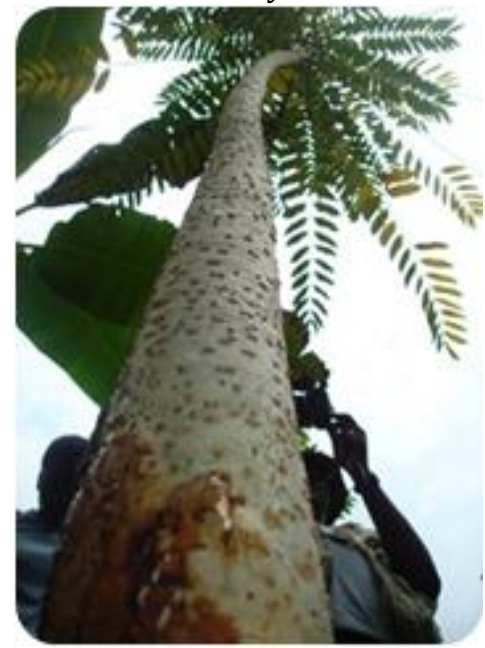

Figure 3b. Disease in Cedrela odorata plantations.
(Figure 3a). About $68 \%$ and $87 \%$ of plantations in Tano Nimri and Mamiri forest reserves, respectively were affected and cleared resulting in huge economic losses to the developers. Armillaria hemii was identified on the roots and base of affected trees as in the teak plantations (Figure 3).

Defoliation and dieback were observed in one to twoyear-old trees in Yaya and Asubima respectively. Drought-related stunting appeared to be a common problem in the one to two-year-old plantations in Afram Headwaters, especially in areas with dry weather.

Diseases of Ceiba pentandra: In the nursery at 
Mankrang, leaf spot and dieback were observed on seedlings at the onset of the rainy season in April. In Pra Anum and Asenanyo, dieback and mortality occurred in saplings of between one to four-year-olds. The severity of these infections resulted in $90-100 \%$ losses in the nursery depending on the provenances and $50-70 \%$ in plantations. Leaf spot was caused by Colletotrichum capsici, whereas Fusarium solani and Lasiodiplodia theobromae were associated with dieback of stems in both nursery and field.

Diseases of Eucalyptus species: Low levels of disease $(<1.0 \%)$ were observed in Eucalyptus plantations; however, Cylindrocladium leaf blight was common on Eucalyptus trees in plantations of APSD Ghana Limited. A Calonectria species was also found causing rot in the nursery.

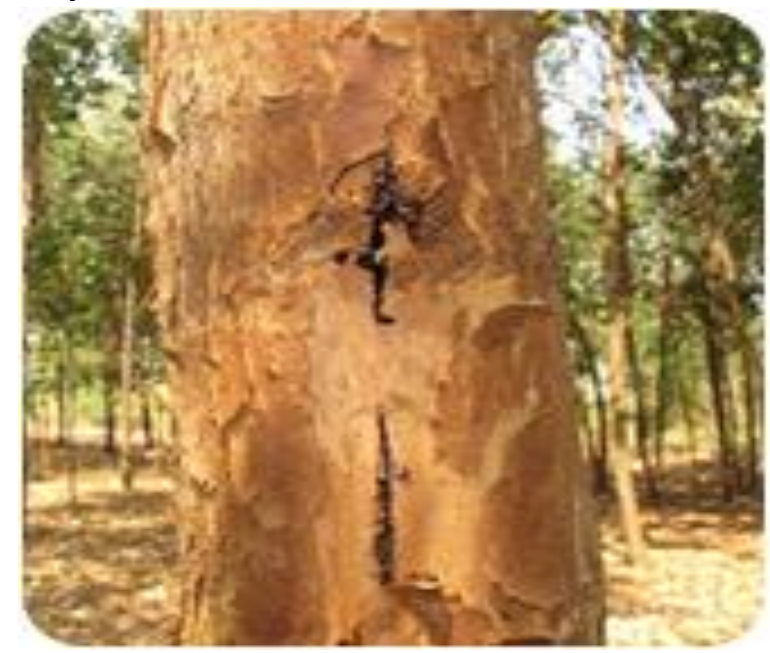

Figure 4. Botryosphaeria canker on trunk of Eucalyptus tree.

Isolated cases of disease caused by species of Botryosphaeria (Figure 4), Pestalotiopsis and Phomopsis (Diaporthe) were observed on branches and trunks of Eucalyptus argophloia and E. grandis hybrids. Species of Mycosphaerella and Teratosphaeria were isolated from leaf spot symptoms while Quambalaria eucalypti was found on a single E. grandis tree.

\section{DISCUSSION}

Defoliation, dieback and stunted growth were found in ten out of 17 teak plantations in one to two-year-old saplings as a result of drought during the dry season. This is similar to observations made in Indonesia by Widyastuti and Widyastuti (2002). Poor tree health was considered to have significant impact on plantation production, particularly during the early phase of establishment by tree growers (Mohd Farid et al., 2005).
Generally, majority of the plantations surveyed were free from root disease. Root disease was found in only two out of the twenty forest reserves surveyed. In these reserves basal root rot was present in both teak and cedrela plantations. Disease infection on teak was recorded seven years after planting in the Mamiri forest reserve. However, Mazia and Lee (1999) have reported teak trees aged two years and above were frequently infected by root disease in Malaysia.

In Ghana, signs and symptoms of pathogen attack were visible on stems and roots of cedrela and teak trees and were of high incidence and severity (68.3\%) in cedrela and minor (1.5\%) in teak). The first visible symptom of root disease was gradual yellowing of leaves followed by shedding of leaves and decay of most root system. Spread of disease to adjacent healthy trees was primarily through root contact. Earlier work by Tewari (1992) reported that this was the most common mode of disease spread in plantation-grown teak. Frequently, the source was infected old stumps and wood debris remaining in the soil or standing diseased trees.

Armillaria hemii was identified on the roots and root collars of affected teak and cedrela plantations in Mamiri and Tano Nimri forest reserves. Wilting and yellowing of tree crowns as well as occurrence of white mycelial fans under the bark of infected teak trees were common symptoms of Armillaria infections (Morrison et al., 1991). Armillaria hemii has been reported to have infected trees (Eucalyptus, Pinus, Acacia, Grevillea and Cupressus species) in several countries in south, central, east and western Africa (Coetzee et al., 2000; Mwenje and Ride, 1996; Gezahgne et al., 2003). Armillaria root rot exists naturally in dense rain forest zones where annual rainfall exceeds $1,300 \mathrm{~mm}$. Clearing the forest breaks this natural equilibrium and causes pre-existing infection centres to spread in the new plantations. Thus the incidence of pathogens in young plantations depends on the previous density of inoculum in the forest (Nandris et al., 1987). Mohd Farid et al. (2005) indicated that root rot disease was found mostly in plantations with poor land preparation, where stumps and wood debris have been left on the ground to decay.

Outbreaks of leaf spot in Ceiba pentandra which resulted in dieback caused high mortality $(70-100 \%)$ in nurseries established in Mankrang and Pra Anum. Reports have been made on leaf spot of C. pentandra in Assam, Madya Pradesh and Uttar Pradesh in India 
where the disease was first detected in seedlings at the nursery. The disease was destructive and damaged as much as $40 \%$ of the leaf area (Mehrothra, 1989). Colletotrichum capsici was identified as the causal agent of leaf spot in the nursery whereas Fusarium solani and Lasiodiplodia theobromae were associated with dieback of stems in both nursery and field. However, in Nagpur, India, dieback and canker were caused by Colletotrichum gloeosporioides (syn. Glomerella cingulata) in established trees of $C$. pentandra (Charkrabarty et al., 1993).

On branches of Eucalyptus argophloia and E. grandis hybrid plantations in APSD, isolated cases of diseases caused by species of Botryosphaeria were observed. Botryosphaeria species are known to be saprophytes and opportunistic pathogens (Barnard et al., 1987; Shearer et al., 1987; Smith et al., 1994) on Eucalyptus species. However, these are viewed as latent pathogens that occur on leaf and branch tissues of healthy woody plants which later cause disease when trees are stressed (Fisher et al., 1993; Smith et al. 1996) due to drought, frost, waterlogging and insect damage (Old et al., 1990). In South Africa, wide-spread twig dieback and stem cankers caused by Botryosphaeria dothidea and B. eucalyptorum were observed on E. grandis, $E$. nitens and E. smithii, clones of E. grandis, hybrids of $E$. grandis with E. camaldulensis, as well as on E. urophylla (Smith et al., 1994, 2001). Since the Eucalyptus plantations in Ghana are being developed on marginal soils where moisture is a limiting factor there is the need for careful matching of planting stock to site to avoid stress-induced damage.

Cylindrocladium leaf blight affected young trees in Eucalyptus plantations of APSD Ghana Limited. Cylindrocladium are common pathogens of Eucalyptus and Acacia species particularly in nurseries (Crous et al., 1991) causing damping off of young seedlings as well as leaf defoliation, shoot blight and cankers on the stems of young plants. In Kenya and Uganda young seedlings of Eucalyptus showed signs of Cylindrocladium infection, including damping off and stem cankers. Since Cylindrocladium infection is common on Eucalyptus trees in nurseries, it is a potential threat to plantation establishment in the country.

A species of Mycosphaerella was isolated from leaf spot on an E. grandis tree. Several Mycosphaerella species have been reported from southern and east Africa and found to display differences in host range and age with regard to infection of leaves (Crous, 1998; Hunter et al., 2004). Some Mycosphaerella species are capable of causing more serious disease on mature foliage in Australia and South East Asia (Crous, 1998; Crous et al., 1998; Wingfield et al., 1996) and every effort must be made to exclude them from African countries.

\section{CONCLUSIONS}

Although several forest tree plantations have been established under the National Forest Plantation Development Programme in the different forest districts of Ghana, survey was undertaken only in a limited number of plantations. The study found new records of exotic diseases with no serious management of the pathogens by plantation developers. Suggestions have been made for stump removal and trenching in areas affected with root rot, removal of infected trees, proper farm maintenance culture, sanitation and thinning followed by insecticide and fungicide application. Establishment of new plantations should take into account the presence of pathogens causing these diseases and also match planting stock to site to avoid stress. There is also the need to establish plantation health networks to monitor, protect and prevent introduction of new pathogens with the increase in new tree plantations.

\section{ACKNOWLEDGEMENT}

Funding for the research and survey was provided by the African Development Bank (AfDB), Forestry Commission, APSD Ghana Ltd., National Research Foundation (NRF) of South Africa and the Forestry and Agricultural Biotechnology Institute (FABI), University of Pretoria.

\section{REFERENCES}

Apetorgbor, M. M., Mancini, F., Turco, E., Cobbinah, J. R. and Ragazzi, A. 2003. The involvement of fungal pathogens in dieback decline of Milicia excelsa saplings in plantations. Journal of Plant Diseases and Protection 108 (6): 568-577.

Apetorgbor, M. M., Siaw, D. E. K. A. and Gyimah, A. 2003. Decline of Ceiba pentandra seedlings, a tropical timber species, in nurseries and plantations. Ghana Journal of Forestry 11: (2) 51-62.

Arora, D. 1986. Mushrooms demystified: A comprehensive guide to the fleshy fungi. 2nd Edition. Ten Speed Press, Berkeley, USA. pp 959.

Barnard, E. L., Geary, T., English, J. T., Gilly, S. P. 1987. Basal cankers and coppice failure of Eucalyptus grandis in Florida. Plant Disease 71: 358-361. 
Brayford, D. 1997. International course on the identification of fungi of agricultural and environmental significance. International Mycological Institute, Kew, Surrey, UK.

Benhin, J. K. A., Barbier, E. B. 2001. The effects of adjustment in Ghana of the structural program on deforestation. Agricultural and Resource Economics Review 30 (1): 66-80.

Bosu, P. P. and Apetorgbor, M. M. 2009. Rising pest problems in forest plantations in Ghana. Technical Note No. 2. 9pp.

Coetzee, M. P. A., Wingfield, B. D., Coutinho, T. A. and Wingfield, M. J. 2000. Identification of the causal agent of Armillaria root rot of Pinus species in South Africa. Mycologia 92: 777-785.

Chakrabarty, P. K., Meshram, M. K., Sheo, R., Raj, S. 1993. An outbreak of dieback and canker in white silk cotton (Ceiba pentandra). Indian Journal of Agricultural Sciences 63(9): 599-601.

Crous, P. W. 1998. Mycosphaerella spp. and their anamorphs associated with leaf spot diseases of Eucalyptus. Mycol. Mem. 21: 1-170.

Crous, P. W., Phillips, A. J. L. and Wingfield, M. J. 1991. The genera Cylindrocladium and Cylindrocladiella in South Africa, with special reference to forest nurseries. South African Forestry Journal 157: 6985.

Crous, P. W., Wingfield, M. J., Mohammed, C. and Yuan, Z. Q. 1998. New foliar pathogens of Eucalyptus from Australia and Indonesia. Mycol. Res. 102: 527-532.

Fisher, P. J., Petrini, O. and Sutton, B. C. 1993. A comparative study of fungal endophytes in leaves, xylem and bark of Eucalyptus nitens in Australia and England. Sydowia 45: 1-14.

Foli, E. G., Agyeman, V. K. and Pentsil, M. 2009. Ensuring sustainable timber supply in Ghana: A case for plantations of indigenous timber species. Technical Note No. 1 15pp.

Food and Agricultural Organization of the United Nations (FAO). 2010a. Global resources assessment 2010. Country Report, Ghana. FRA 2010/077, Rome.

Forest Commission 2007. Ghana Forestry Commission, Annual Report, Accra.

Gezahgne, A., Roux J. and Wingfield, M. J. 2003.Diseases of exotic plantation Eucalyptus and Pinus species in Ethiopia. South African Journal of Science 99: 29-33.
Hunter, G. C., Roux, J., Wingfield, B. D., Crous, P. W. and Wingfield, M. J. 2004.

Mycosphaerella species causing leaf disease in South African Eucalyptus plantations. Mycol. Res. 108: 672-681.

Maziah, Z. and Lee, S. S. 1999. Diseases and disorders of teak (Tectona grandis) in Peninsular Malaysia. In: Tropical plant protection in the information age. Eds. Sivapragasam, A., et al., Proceedings of the Fifth International Conference on Plant Protection in the Tropics. 15-18 March 1999, Kuala Lumpur, Malaysia, 158-163.

Mehrothra, M. D. 1989. Corynespora cassiicola leaf spot of Ceiba pentandra and its control in the nursery. India Forester 115(12): 905-909.

Ministry of Environment and Science (MES). 2002. National biodiversity for Ghana. 55 pp.

Mohd Farid, A., Lee, S. S., Maziah, Z., Rosli, H. and Norwati, M. 2005. Basal root rot, a new disease of Teak (Tectona grandis) in Malaysia caused by Phellinus noxius. Malaysia Journal of Microbiology 1(2): 40-45.

Morrison, D. J., Williams, R. E. and Whitney, R. D. 1991. Infection, disease development, diagnosis and detection. In: Armillaria Root Rot Disease. Eds. Shaw, C. J., Kile, G. A. Agriculture Handbook No. 691. Washington, DC: Forest Service, United States Department of Agriculture, pp. 62-75.

Mwenje, E. and Ride, J. P. 1996. Morphological and biochemical characterization of Armillaria isolates from Zimbabwe. Plant Pathology 45: 1031-1051.

Nandris, D., Nicole, M. and Geiger, J. P. 1987 .Root rot disease of rubber. Plant Disease 71: 298-306.

Ofosu-Asiedu, A. 1988. Some destructive Diseases of Tree crops in Africa, South of the Sahara. $5^{\text {th }}$ ICPP Meeting, 20-27 August, 1988. Kyoto, Japan.

Old, K. M., Gibbs, R., Craig, I., Myers, B. J. and Yuan, Z.Q. 1990. Effect of drought and defoliation on the susceptibility of Eucalyptus to canker caused by Endothia gyrosa and Botryosphaeria ribis. Australian Journal of Botany 38:571-581.

Roux, J. and Apetorgbor, M. M. 2009. First report of Chrysoporthe cubensis from Eucalyptus in Ghana. New Disease Reports 20.

Ryvarden, L., Piearce, G. D. and Masuka, A. J. 1994. An introduction to the Larger fungi of South Central Africa. Baobab books. pp200.

Shearer, B. L., Tippett, J. T. and Bartle, J. R. 1987. 
Botryosphaeria ribis infection associated with death of Eucalyptus radiata in species selection trials. Plant Disease 71: 140-145.

Smith, H., Crous, P. W., Wingfield, M. J., Coutinho, T. A. and Wingfield, B. D. 2001. Botryosphaeria eucalyptorum sp., a new species in the B. dothideacomplex on Eucalyptus in South Africa. Mycologia 93: 277-284.

Smith, H., Kemp, G. H. J. and Wingfield, M. J. 1994. Canker and dieback of Eucalyptus in South Africa caused by Botryosphaeria dothidea. Plant Pathology 43: 1031-1034.

Smith, H., Wingfield, M. J. and Pertini, O. 1996. Botryosphaeria dothidea endophytic in Eucalyptus grandis and Eucalyptus nitens in South Africa. Forest Ecology and Management 89: 189-195.
Tewari, D. N. 1992. A monograph on teak (Tectona grandis Linn. f.). International Book Distributors, 479pp.

Wagner, M. R., Cobbinah, J. R. and Bosu, P. P. 2008. Forest Entomology in Tropical Africa: Forest Insects of Ghana. $2^{\text {nd }}$ Edition. Springer Science and Business Media B. V. 244pp.

Widyastuti, S. and Widyastuti, S. M. 2002. The incidence of pests and diseases on Teak plantation grown from tissue culture in Kendal Forest District, Central Java. Pakistan Journal of Biological Sciences 5(3): 438-441.

Wingfield, M. J., Crous, P. W. and Boden, D. 1996. Kirramyces destructans sp., a serious leaf pathogen of Eucalyptus in Indonesia. South African Journal of Botany 62: 325-327. 